\title{
Absence of Batf3 results in reduced liver pathology in mice infected with Schistosoma japonicum
}

\author{
Lin Chen ${ }^{1,2^{*}}$, Donghui Zhang ${ }^{1,2,3}$, Wenyue Zhang ${ }^{1,4}$, Yuxiao Zhu ${ }^{1,2}$, Min Hou ${ }^{1,2}$, Bingya Yang ${ }^{1,2}$, Zhipeng Xu,2,
} Minjun $\mathrm{Ji}^{1,2}$ and Guanling $\mathrm{Wu}^{1,2}$

\begin{abstract}
Background: The involvement of $C D 8^{+} T$ cells in schistosomiasis is being increasingly appreciated, but the underlying mechanism is not well defined.

Results: In this study, we showed that the absence of Batf3 alleviated liver damage in Batf3 ${ }^{-/-}$mice infected with S. japonicum. We found alleviated liver granulomatous inflammation in Batf3 $3^{-1-}$ mice with schistosomiasis japonica could not be attributed to the difference in schistosome egg or worm burden. The stronger Tc1 cell responses observed in Batf3 ${ }^{-1}$ mice suggested that the deletion of Batf3 resulted in more activation of CD8 ${ }^{+} \mathrm{T}$ cells unexpectedly during the natural infection of schistosomes. We detected a small amount of CD8a ${ }^{+} \mathrm{DCs}$ in the spleen of Batf3 ${ }^{-1-}$ mice at $9 \mathrm{w}$ post-infection. This small amount of newly generated CD8a $\mathrm{a}^{+} \mathrm{DCs}$ might contribute to enhanced activation of $\mathrm{CD}^{+} \mathrm{T}$ cells via cross-presentation and activation which then attenuate hepatic pathological damage found in $\mathrm{Batf3}^{--}$mice.
\end{abstract}

Conclusions: Our study provides evidence that Batf3 is associated with the immunoregulation of the liver granuloma formation, which may confer a new options for schistosomiasis treatment.

Keywords: Schistosoma japonicum, Dendritic cells, CD8a ${ }^{+}, \mathrm{CD}^{+}{ }^{+}$T cells, Batf3, Helminth

\section{Background}

A challenging problem in the prevention and treatment of schistosomiasis is re-infection and immunopathological damage of the liver in patients who live in endemic areas $[1,2]$.The secretion of soluble egg antigen (SEA) in the late stage of schistosomiasis causes Th2-dominant immune response to form granulomas [3, 4]. Repeated infection will eventually lead to secondary liver fibrosis and advanced schistosomiasis, and patients may have upper gastrointestinal bleeding, hepatic coma and other serious complications, and even death [2].

Current studies on the immune mechanism of schistosomiasis infection have focused on $\mathrm{CD} 4^{+} \mathrm{T}$ cells and antibody response. $\mathrm{CD}^{+} \mathrm{T}$ cells play an important role in

\footnotetext{
* Correspondence: linchen@njmu.edu.cn

'Department of Pathogen Biology, Nanjing Medical University, Nanjing, Jiangsu, China

${ }^{2}$ Jiangsu Province Key Laboratory of Modern Pathogen Biology, Nanjing, Jiangsu, China

Full list of author information is available at the end of the article
}

host defense against bacterial, viral, protozoa infection and anti-tumor processes, however, the role of $\mathrm{CD}^{+} \mathrm{T}$ cells in parasitic helminth infection, such as schistosomiasis, remains unclear. $\mathrm{CD}^{+} \mathrm{T}$ cells recognize the antigenic peptide presented by the MHCI molecule and kill the target cells, or induce apoptosis of the target cells by direct contact (secretion of perforin, granzyme, lymphotoxin, or by Fas / FasL pathway). Schistosomes can adsorb host MHCI, suggesting that host CTL may play a role in the immune response to multicellular worms [5]. Chensue et al. [6] proposed that modulated granulomatous inflammatory response was maintained by effector and regulator lymphocytes in mice with chronic infection of Schistosoma mansoni. Among those studied, Ly- $2^{+}$ $\left(\mathrm{CD}^{+}\right) \mathrm{T}$ lymphocytes were primarily responsible for suppressing granuloma formation. Another study [7] found that during the chronic infection stage of S. mansoni, $\mathrm{CD}^{+} \mathrm{T}$ cell activity increased, which can significantly reduce the growth of egg granuloma, and the 
subsequent formation of new granulomas was significantly slower at 16-20 weeks post-infection. When lymph nodes and spleen cells in chronic stage of infection were transferred to acutely infected mice, they can significantly reduce granuloma formation in the recipients. However, when the $\mathrm{CD}^{+} \mathrm{T}$ cells were removed from these cells, the inhibition effect on granuloma disappeared [8]. Pancré et al. [9, 10] reported that single immunization of $S$. mansoni recombinant glutathione S-transferase (rSm28GST) induced the immunity to the infection of schistosomiasis and increased spleen $\mathrm{CD}^{+} \mathrm{T}$ cell activity, resulting in antigen-specific CTL response. Sm28GST-specific $\mathrm{CD} 8^{+} \mathrm{T}$ cells were further passively transferred to naive mice, after the infection of schistosomiasis, the number of liver granuloma reduced, and liver fibrosis alleviated in the mice. However, after treatment with anti-CD8 antibody, the protective effect mediated by Sm28GST was significantly reducedx. Consistent with the above studies, our previous study in $T L R 2^{-/-}$, $T L R 4^{-/-}$mice and pigs suggest that CTL responses are involved in the immune mechanism of resistance to $S$. japonicum infection $[11,12]$.

Moreover, $\mathrm{CD}^{+} \mathrm{T}$ cells secrete inflammatory factor IFN$\gamma$ to regulate immune response and reduce pathological damage during the infection of $S$. mansoni. $\mathrm{CD} 8^{+} \mathrm{T}$ cells in the spleen of mice infected with S. mansoni responded to schistosome antigen presented by APC and produced IFN- $\gamma$ [13]. After $S$. mansoni infection, 4 weeks of IFN- $\gamma$ intramuscular injection reduced collagen deposition in mouse liver significantly [14]. In the spleen of mice infected with $S$. mansoni, the number of $\mathrm{CD}^{+} \mathrm{T}$ cells decreased, type 2 immune environment established and further led to the apoptosis of $\mathrm{Tc} 1\left(\mathrm{CD}^{+} \mathrm{CD} 8^{+} \mathrm{IFN}-\gamma^{+}\right)$cell. Thus, schistosomes may inhibit type 1 immune response by reducing Tc1 cells to facilitate the deposition of eggs and cause pathological damage [15].

Taken together, $\mathrm{CD} 8^{+} \mathrm{T}$ cells may play an immunological role in anti-schistosomiasis infection. However, the mechanism by which $\mathrm{CD} 8^{+} \mathrm{T}$ cell response is generated in schistosome infection remains unclear. In this study, we found the absence of Batf3 alleviated liver damage in Batf $3^{-/-}$ mice infected with $S$. japonicum and that the alleviated liver granulomatous inflammation could not be attributed to the difference in schistosome egg or worm burden. The stronger Tc1 cell responses observed in Batf $3^{-/-}$mice suggested that the deletion of Batf 3 activated $\mathrm{CD} 8^{+} \mathrm{T}$ cells unexpectedly during the natural infection of schistosomes. Then we detected a small amount of $\mathrm{CD} 8 \alpha^{+}$DCs in the spleen of $\mathrm{Batf}^{-/-}$mice at 9w post-infection. This small amount of newly generated $C D 8 \alpha^{+} \mathrm{DCs}$ may have a more powerful function in cross-presenting and activate $\mathrm{CD} 8^{+} \mathrm{T}$ to secret IFN- $\gamma^{+}$which can attenuate hepatic pathological damage in $\mathrm{Batf3}^{-/-}$mice.

\begin{abstract}
Methods
Mice

B6.129S(C)-Batf3 $3^{\text {tm1Kmm }} / \mathrm{J}$ mice (Stock No: 013755/

Batf $^{-/-}$) were purchased from Jackson Labs [16]. Wild-type C57BL/6 J (B6) mice were purchased from the Model Animal Research Center, Nanjing University (Nanjing, China). 6-8 weeks old female mice were used in all experiments. All mice were maintained according the institutional guidelines at Nanjing Medical University.
\end{abstract}

\section{Parasites and infections}

Schistosoma japonicum cercariae were maintained in Oncomelania hupensis snails (laboratory-infected with a Chinese mainland strain), which were purchased from the Jiangsu Institute of Parasitic Disease (Wuxi, China). Snails were placed in deionized water and exposed to incandescent light for 3-4 h for cercarial release. For infection, the cercariae were counted and placed on glass cover slips by a $10 \mu \mathrm{l}$ bacteriological loop. Batf $3^{-/-}$and B6 mice were infected with $10 \pm 2 \mathrm{~S}$. japonicum cercariae through their shaved abdomens.

\section{Parasitological assessments}

For parasite burden determination (adult worm recovery, egg burdens and area of single egg granuloma in the livers), all mice were sacrificed 9 weeks post-infection. The worms were collected and counted through perfusion of the portal vein with PBS. After perfusion, the intestinal tract of each mouse was examined for residual worms. The liver samples, except left front lobes, of each mouse were weighted and digested in $5 \% \mathrm{KOH}$ for $18 \mathrm{~h}$ at $37^{\circ} \mathrm{C}$. Each liver sample was counted 3 times for released eggs under the microscope and the mean count was used as eggs per gram (EPG) in mice. Left front lobes of livers from each mouse were fixed in $4 \%$ paraformaldehyde, embedded in paraffin and stained with haematoxilin and eosin according to standard protocols. Single-egg granulomas were examined and their sizes were calculated using AxioVision Rel 4.7 (Carl Zeiss $\mathrm{GmbH}$, Jena, Germany). At least 10 single egg granulomas per liver section were photographed. Sirius red stainings were observed to investigate the deposition of collagen fibers in liver of $\mathrm{Batf}^{-/-}$and B6 mice at 9 weeks post-infection and the results were analyzed using imageJ software (National Institutes of Health, America).

\section{Flow cytometry detection}

Percentages of Th1 $\left(\mathrm{CD}^{+}{ }^{+} \mathrm{CD} 4^{+} \mathrm{IFN}-\gamma^{+}\right)$, Th2 $\left(\mathrm{CD}^{+} \mathrm{CD} 4\right.$ $\left.{ }^{+} \mathrm{IL}-4^{+}\right), \mathrm{Tc} 1\left(\mathrm{CD}^{+}{ }^{+} \mathrm{CD} 8^{+} \mathrm{IFN}-\gamma^{+}\right), \mathrm{Tc} 2\left(\mathrm{CD} 3^{+} \mathrm{CD} 8^{+} \mathrm{IL}-4^{+}\right)$ cells in the spleens of $\mathrm{Batf3}^{-1-}$ and B6 mice at 0, 3, 6 and 9 weeks post-infection was detected by flow cytometry. Splenocytes were prepared by gently forcing spleen tissue through a nylon net into incomplete RPMI-1640 
medium (Gibco-Invitrogen, Grand Island, NY, USA) supplemented with $100 \mathrm{U} / \mathrm{ml}$ penicillin and $100 \mathrm{U} / \mathrm{ml}$ streptomycin (Gibco-Invitrogen), followed by red blood cell $(\mathrm{RBC})$ lysis to remove erythrocytes. Then $2.0 \times 10^{6}$ splenocytes cells were stimulated with ionomycin $(1 \mu \mathrm{g} /$ $\mathrm{ml})$ and PMA $(25 \mathrm{ng} / \mathrm{ml})$ in the presence of $10 \mu \mathrm{g} / \mathrm{ml}$ Brefeldin-A (Enzo Life Science, New York, USA) for $6 \mathrm{~h}$ at $37{ }^{\circ} \mathrm{C}$ in $5 \% \mathrm{CO}_{2}$. After $6 \mathrm{~h}$, the cells were surface stained with APC-anti-CD3e, FITC-anti-CD4 (or CD8). Subsequently, the cells were washed, fixed and permeabilized with Cytofix/Cytoperm buffer and stained with PE conjugated antibodies against IFN- $\gamma$ or IL-4 (or isotype IgG2a control antibody) (eBioscience, San Diego, CA, USA) following the manufacturer's instruction. Stained cells were detected by flow cytometry (Becton Dickinson) and the data were analyzed using FlowJo7.6 software.

\section{Real-time polymerase chain reaction}

Total RNA was extracted from $1 \times 10^{6}$ splenocytes using TRIzol reagent (Invitrogen, Life Technologies Carlsbad, CA, USA). The cDNA was synthesized with PrimeScript RT reagent kit (Takara, Otsu, Shiga, Japan) according to the manufacturer's protocol. PCR was performed on the ABI PRISM 7300 (Applied Biosystems, USA) using Power SYBR Green PCR Master Mix (Applied Biosystems, USA). Primers specific for $\beta$-actin, Batf3, Irf8 and PU.1 are listed in Table 1. PCR cycling protocol was as follows: $50{ }^{\circ} \mathrm{C}$ for $2 \mathrm{~min}, 95{ }^{\circ} \mathrm{C}$ for $10 \mathrm{~min}$, followed by 40 cycles at $95{ }^{\circ} \mathrm{C}$ for $15 \mathrm{~s}, 60^{\circ} \mathrm{C}$ for $1 \mathrm{~min}$. The housekeeping gene $\beta$-actin was used as an internal control and the data were analyzed with 7300 System SDS Software v1.2.1 (Applied Biosystems, USA). Quantitation of relative mRNA expression was calculated using the $2^{-\Delta \Delta C t}$ method [17].

Table 1 Primer sequences of Irf8, PU.1, Batf3, Id2, Nfil3 genes used in the RT-PCR

\begin{tabular}{|c|c|c|}
\hline & & sequence $\left(5^{\prime} \rightarrow 3^{\prime}\right)$ \\
\hline \multirow[t]{2}{*}{$\beta$-actin } & sense & TTCCTTCTTGGGTATGGAAT \\
\hline & antisense & GAGCAATGATCTTGATCTTC \\
\hline \multirow[t]{2}{*}{ Irf8 } & sense & GGGTCAGTACACAACAGGGG \\
\hline & antisense & CTAGCTGCGTGGAGCATGTA \\
\hline \multirow[t]{2}{*}{ PU.1 } & sense & CCTCGATACTCCCATGGTGC \\
\hline & antisense & GGCTGGGGACAAGGTTTGAT \\
\hline \multirow[t]{2}{*}{ Batf3 } & sense & TITGTGCAGCTTCGGTCAGA \\
\hline & antisense & CCGGACAAAGGAGGAGTGAG \\
\hline \multirow[t]{2}{*}{ Id 2} & sense & CGGGGCTGATCTGGGAAAAT \\
\hline & antisense & CACAGCGTAACCTCGTCTTC \\
\hline \multirow[t]{2}{*}{ Nfil3 } & sense & ATGTTACAGGCGTGCAAAATGG \\
\hline & antisense & TGATCGCTATGGCTITCTCCA \\
\hline
\end{tabular}

\section{Statistical analysis}

Statistical analyses were performed using GraphPad Prism version 5.01 for Windows(USA, GraphPad Software). The data are expressed as mean \pm SEM. Student's $t$-test and one-way analysis of variance (ANOVA) were performed to test for differences. For all tests, significance was considered for $P<0.05$.

\section{Results}

The number of $C D 8 a^{+} D C s$ changed consistently with the trend of Th1 response during the infection with $S$.

\section{japonicum}

We established mouse model of schistosomiasis infection in $\mathrm{B} 6$ mice and detected the number of $\mathrm{CD} 8 \alpha^{+} \mathrm{DCs}$ in the spleen at $0,3,6$ and 9 weeks post-infection. We found that the number of $\mathrm{CD} 8 \alpha^{+} \mathrm{DCs}$ increased quickly after infection and reached a peak at 3 weeks after infection, beginning to decrease from 6 weeks post-infection to the lowest point at 9 weeks post-infection $\left(F_{(3,12)}=300.9, P<0.0001\right)$ (Fig. 1$)$. This change was consistent with the trend of Th1 response during $S$. japonicum infection. In the initial 2-4 weeks after infection, under the stimulation of migrating schistosomula, the host showed Th1 type (IFN- $\gamma$, TNF) response. Once egg production begins, Th1 type response declined rapidly, and Th2 type (IL-4, IL-13, IL-10, IL-5) response started $[18,19]$.

Batf3 null mutation alleviates mouse liver granulomatous inflammation in S. japonicum infection

To evaluate the role of $\mathrm{CD} 8 \alpha^{+}$DCs in schistosome infection, we used $\mathrm{Batf}^{-/-}$mice which lack splenic $\mathrm{CD} 8 \alpha^{+} \mathrm{DCs}$, because of the deletion of Batf3 (Fig. 1c), to establish a schistosome infection model. We found that the granulomas developed after the deposition of parasite eggs in the livers of both Batf3 $3^{-/-}$and WT control B6 mice. The average size of liver granuloma in $\mathrm{Batf}^{-/-}$ mice was significantly smaller than that in the B6 mice at 9 weeks post-infection $\left(t_{(24)}=2.952, P=0.0121\right.$, Fig. $2 \mathrm{a}, \mathrm{b})$. The average integrated optical density (AOD) in $\mathrm{Batf}^{-/-}$mice was significantly lower than that in the B6 mice at 9 weeks post-infection $\left(t_{(21)}=2.141, P=0.0441\right.$, Figs. 2a, c) which indicated less deposition of collagen fibers in liver of $\mathrm{Batf}^{-1-}$ mice. These data suggest that $\mathrm{CD} 8 \alpha^{+}$DCs may be involved in the regulation of the granulomatous response to $S$. japonicum infection.

\section{Similar worm and egg burdens in $\mathrm{Batf}^{-/-}$and B6 mice infected with S. japonicum}

After infection, schistosomula developed into adults and laid eggs; matured schistosome miracidium within eggs can secrete soluble egg antigen (SEA) and cause granulomatous response [20]. To clarify whether the difference of liver granulomatous inflammation between $\mathrm{Batf}^{-1-}$ 

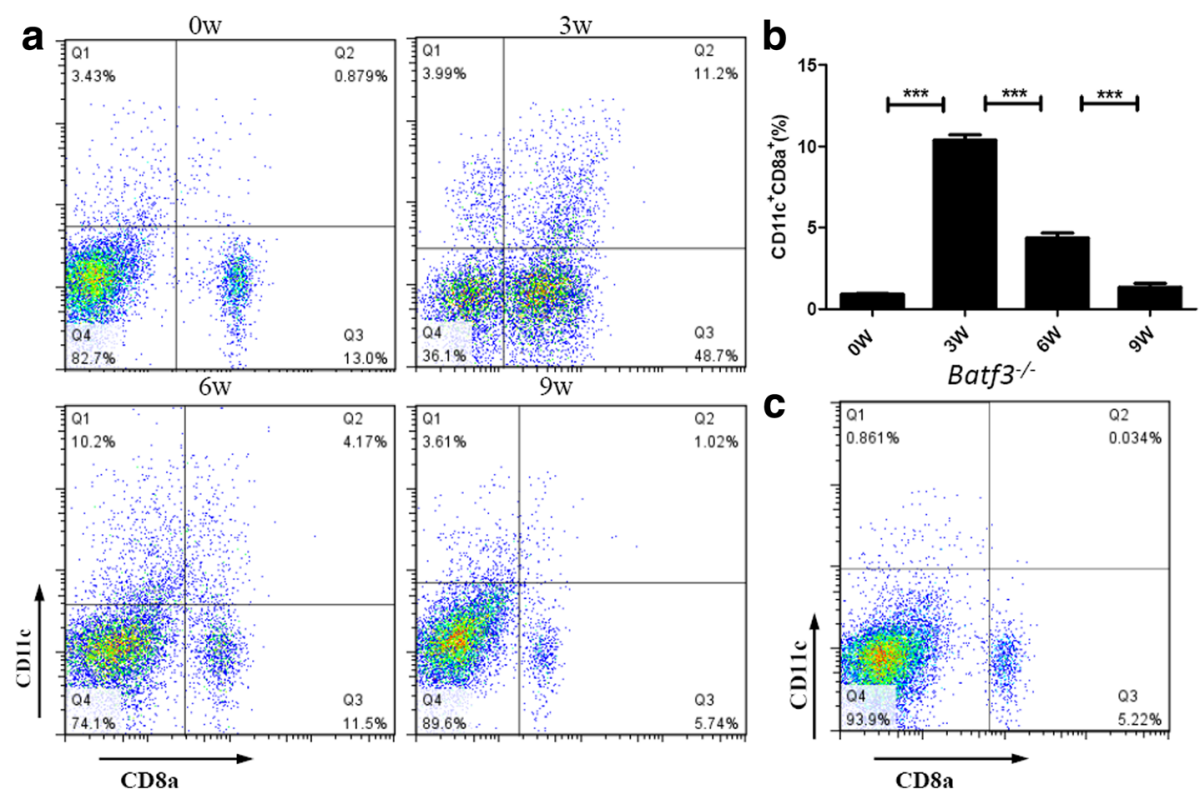

Fig. 1 Dynamic changes of splenic dendritic cells subsets in mice infected with S. japonicum. The number of CD8a ${ }^{+} D C s$ changed consistently with the trend of Th1 response during the infection of S. japonicum. a Percentages of CD11 $c^{+} C D 8 a^{+}$cells analysed by FACS at 0, 3, 6 and 9 weeks post-infection. The upper right quadrant is the proportion of $C D 8 a^{+} D C s$ subsets. $\mathbf{b}$ Percentage of $C D 8 a^{+} D C s$ in the spleen. Data are presented as the means \pm SEM from six mice in each group (*** $P<0.001)$. Results are representative of two independent experiments. $\mathbf{c}$ Percentages of CD11 $c^{+} C D 8 a^{+}$ cells analysed by FACS in Batf3 ${ }^{-/-}$mice. The upper right quadrant is the proportion of CD8a ${ }^{+}$CCs subsets

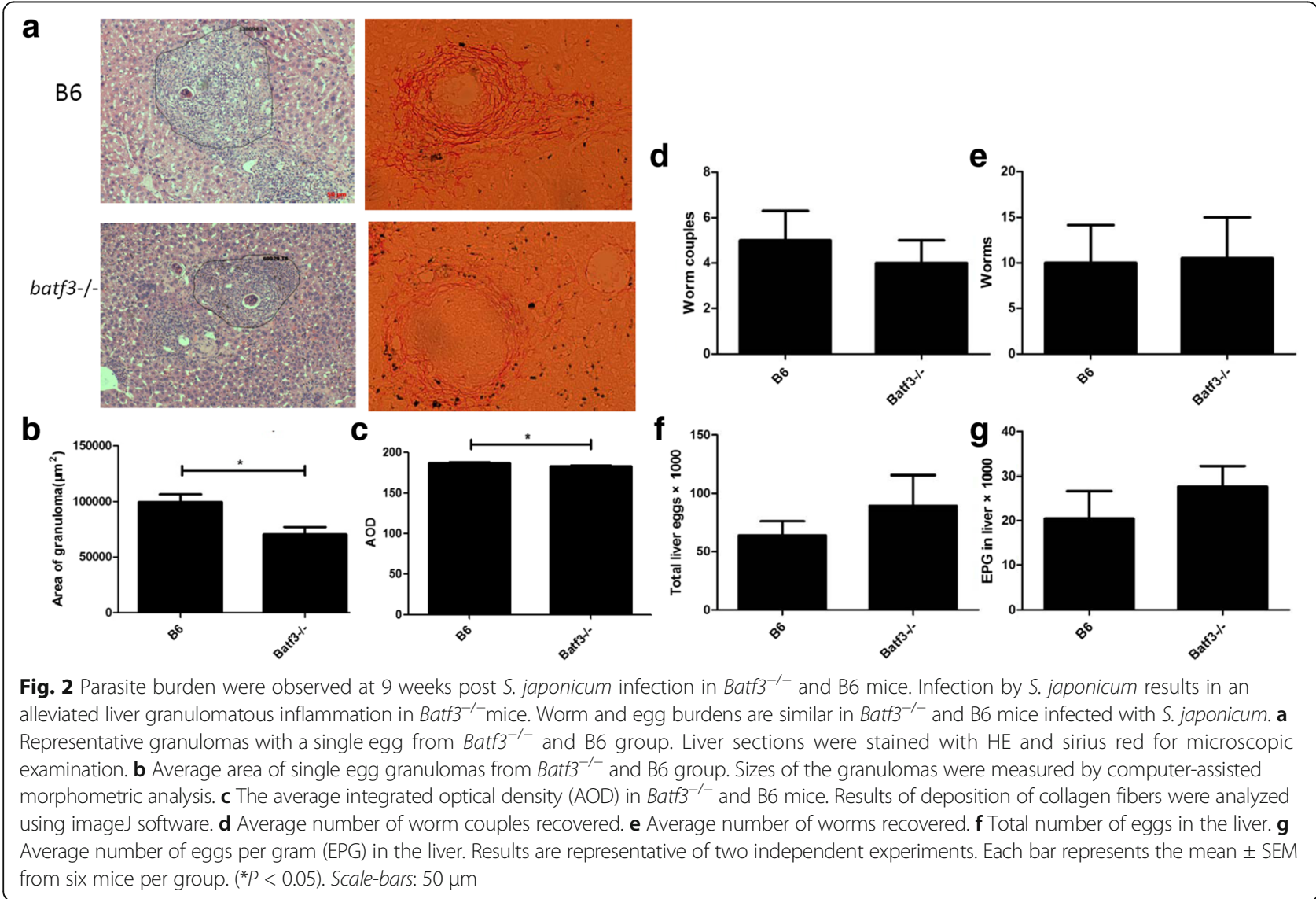


and B6 mice was caused by the different worm and egg burdens, we evaluated parasite burdens of both groups at 9 weeks post-infection and the results showed that there were no significant differences in the numbers of paired worms $\left(t_{(12)}=0.4924, P=0.6483\right)$ (Fig. $2 \mathrm{~d}$ ), adult worms $\left(t_{(12)}=0.07892, P=0.9421\right)$ (Fig. 2e), total liver eggs $\left(_{(12)}=0.8675, P=0.4109\right)$ (Fig. 2f) and EPG in the liver $\left(t_{(12)}=0.9388, P=0.3753\right.$ ) (Fig. 2g) between Batf $3^{-1-}$ and B6 mice. These results indicate that the alleviated liver granulomatous inflammation in $\mathrm{Batf3}^{-/-}$mice with schistosomiasis japonica is caused by other mechanisms rather than the difference in schistosome egg or worm burden.

\section{Tc1 cell responses are stronger in S. japonicum infected} Batf $^{-1-}$ mice

After infection, migrating schistosomula triggered Th1 polarization, which can downregulate hepatic granuloma formation by secreting INF- $\gamma[21,22]$. Egg production can change the immune response to a bias of Th2 (caused by SEA), which can promote the liver lesion $[21,23]$. Thus, we detected Th1 $\left(\mathrm{CD}^{+} \mathrm{CD}^{+} \mathrm{IFN}-\right.$ $\left.\gamma^{+}\right)$, Th2 $\left(\mathrm{CD}^{+}{ }^{+} \mathrm{CD} 4^{+} \mathrm{IL}-4^{+}\right), \quad \mathrm{Tc} 1 \quad\left(\mathrm{CD}^{+} \mathrm{CD} 8^{+} \mathrm{IFN}-\gamma^{+}\right)$ and $\mathrm{Tc} 2\left(\mathrm{CD}^{+} \mathrm{CD}^{+} \mathrm{IL}-4^{+}\right)$cell responses in $\mathrm{Batf}^{-1-}$ and B6 mice by flow cytometry. During the first 3 weeks post-infection the percentage of Th1 cells in the spleen increased quickly in both Batf $3^{-1-}$ and B6 mice and then decreased from 6 weeks post-infection, but there was no significant difference in Th1 cells responses between these two groups $\left(F_{(7,15)}=0.01368, P=0.9080\right)$ (Fig. 3a, b). During the first 3 weeks post-infection the percentage of Th2 cells in the spleen increased slowly in both Batf3 ${ }^{-/-}$ and B6 mice, but the proportion of Th2 cells in both $\mathrm{Batf}^{-/-}$and B6 mice experienced a faster increase after 3 weeks, although there was still no significant difference between these two groups $\left(F_{(7,14)}=0.02747, P=0.8700\right)$ (Fig. 3c, d). In addition, the percentage of Tc2 cells in the spleen of both $\mathrm{Batf}^{-1-}$ and B6 mice increased slowly since infection, and then rapidly increased to the top level at 6 weeks post-infection. However, there was no significant difference between these two groups $\left(F_{(7,15)}=1.540\right.$, $P=0.2283$ ) (Fig. $3 \mathrm{~g}, \mathrm{~h}$ ). Figure $3 \mathrm{e}$ and $\mathrm{f}$ shows that in the first 3 weeks post-infection, the increase of the percentage of Tc1 cells in the spleen of both Batf $3^{-/-}$ and B6 mice was accelerated and then decreased from 3 weeks post-infection. Notably, Tc1 cells in Batf $3^{-1-}$ mice were more than those in B6 control mice at 3, 6 and 9 weeks post-infection $\left(F_{(7,15)}=30.85\right.$, $P<0.0001$ ) (Fig. 3e, f). These results suggest a correlation between the lack of $\mathrm{CD} \alpha^{+} \mathrm{DCs}$ and increased generation of Tc1 cells during S. japonicum infection.

\section{Tc1 cell responses induced by Batf3 independent $\mathrm{CD} 8 \mathrm{a}^{+}$} DCs

The stronger Tc1 cell responses observed in Batf3 ${ }^{-/-}$ mice suggested that the deletion of Batf3 activated CD8 ${ }^{+} \mathrm{T}$ cells unexpectedly during the natural infection of schistosome. It is of interest how $\mathrm{CD}^{+} \mathrm{T}$ cells were activated, since there are no $\mathrm{CD} 8 \alpha^{+} \mathrm{DCs}$ in the spleen of uninfected $\mathrm{Batf}^{-/-}$mice (Fig 1c). Surprisingly, there was still a small amount of $\mathrm{CD} 8 \alpha^{+}$DCs in the spleen of $\mathrm{Batf}^{-1-}$ mice at 9 weeks post-infection (Fig. 4a). It was reported that $C D 8 \alpha^{+} D C s$ differentiation is regulated by a series of transcriptional regulators $[16,24]$. We then detected the expression levels of Irf8, PU.1, Id2, Nfil3 and Batf 3 in the spleen of Batf $3^{-/-}$and B6 mice. Compared to wild-type B6 mice, Irf8 expression in $\mathrm{Batf}^{-/-}$mice was higher at $3 \mathrm{w}, 6 \mathrm{w}$ and $9 \mathrm{w}\left(F_{(7,15)}=21.12\right.$, $P<0.0001)$. The expression of $P U .1$ significantly increased at $3 \mathrm{w}$ and $6 \mathrm{w}\left(F_{(7,15)}=7.860, P=0.0004\right)$ (Fig. $4 \mathrm{~b})$. However, there were no significant differences in expression levels of Id2 and Nfil3 between $\mathrm{Batf3}^{-/-}$and B6 mice $\left(F_{(7,15)}=2.635, P=0.0514 ; F_{(7,15)}=1.970\right.$, $P=0.1281$, respectively) (Fig. $4 \mathrm{~b}$ ). Our results suggest that in the absence of Batf3, a small amount of Batf3-independent $\mathrm{CD} 8 \alpha^{+}$DCs might be compensatorily induced in an Irf8-dependent manner.

\section{Discussion}

APC recognizes the endogenous antigen and processes it as antigen peptide-MHCI complex to $\mathrm{CD}^{+} \mathrm{T}$ cells to induce $\mathrm{CD}^{+} \mathrm{T}$ cell response, while it recognizes the exogenous antigens and processes it as antigen peptideMHCII complex to $\mathrm{CD}^{+} \mathrm{T}$ cells to induce Th cell response [25]. The cross-presentation theory provides a basis for the induction of $\mathrm{CD}^{+} \mathrm{T}$ responses during extracellular infection. Dendritic cells are known to be the most powerful APC, and connect innate and adaptive immune responses. The spleen immature DCs of mice can be divided into $\mathrm{CD} 8 \alpha^{+} \mathrm{DCs}$ and $\mathrm{CD} 8 \alpha^{-} \mathrm{DCs}$, according to surface molecular markers [26]. Studies have demonstrated that $\mathrm{CD} 8 \alpha^{+} \mathrm{DCs}$ play a unique role in cross-presenting [27-29].

In this study, we found that the number of $C D 8 \alpha^{+} D C s$ in the spleen of mice infected with $S$. japonicum has the same trend of change with $\mathrm{Tc} 1$ response, suggesting that $\mathrm{CD} 8^{+} \mathrm{T}$ cell response in schistosomiasis infection is likely to be related to the cross-presentation of $\mathrm{CD} 8 \alpha^{+} \mathrm{DCs}$. $\mathrm{CD} 8 \alpha^{+} \mathrm{DCs}$ differentiation is regulated by a series of transcriptional regulators, including interferon regulatory factor 8 (Irf8), nuclear factor interleukin 3 (Nfil3), DNA binding inhibitor of DNA binding 2 (Id2) [24, 30-32], and basic leucine zipper transcriptional factor ATF-like 3(Batf3) [16, 24]. Previous studies suggest that the Batf3 plays a key role in the differentiation of $\mathrm{CD} 8 \alpha^{+}$DCs, $\mathrm{Batf}^{-/}$mice may lose the ability to cross-present cell-associated antigens and soluble 


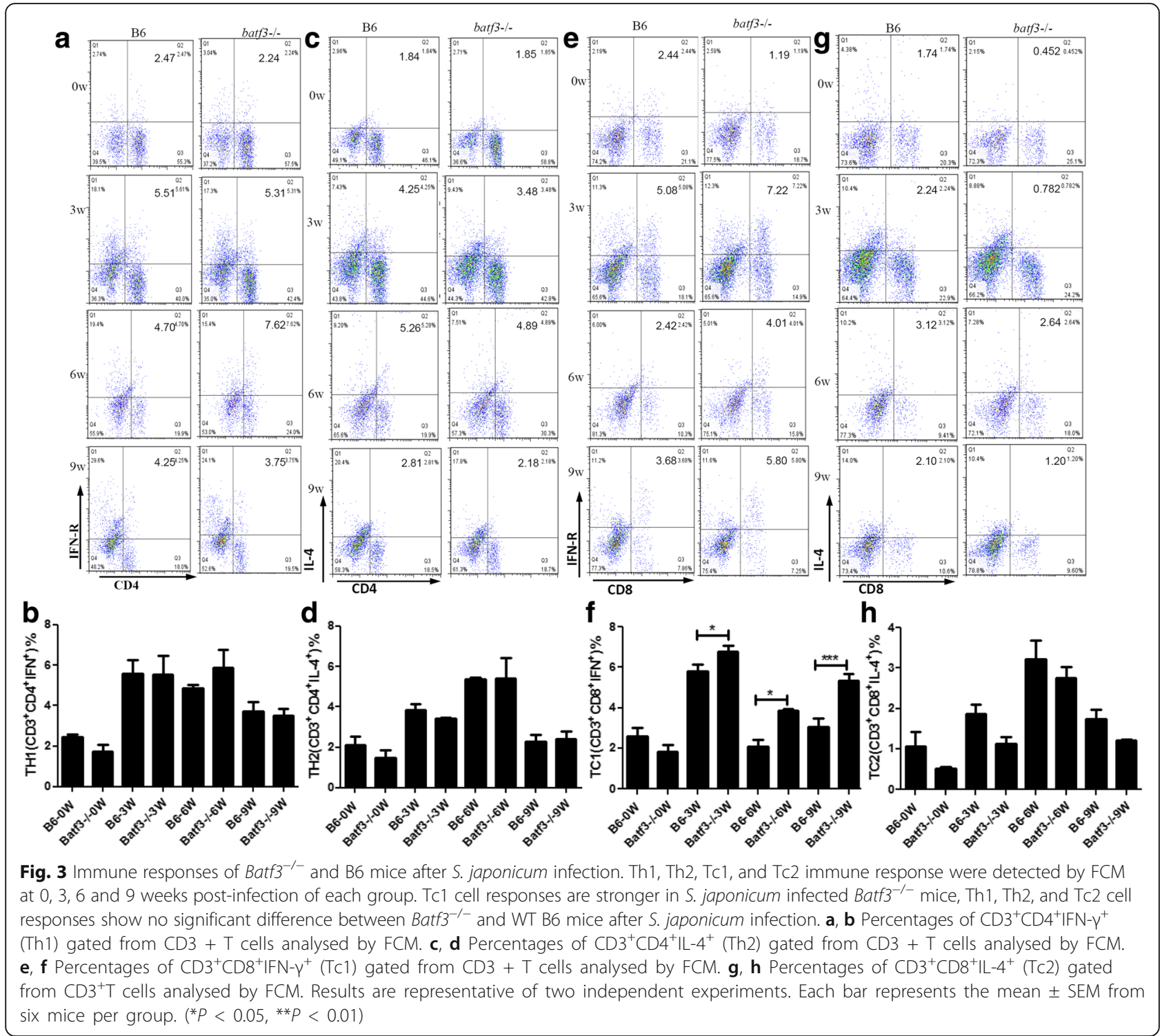

antigens due to the loss of $\mathrm{CD} 8 \alpha^{+} \mathrm{DCs}[16,33,34]$. Hildner et al. [16] reported that $B a t f 3^{-1-}$ mice lack virusspecific $\mathrm{CD}^{+} \mathrm{T}$ cells when infected with West Nile virus, and $B a t f 3^{-/-}$mice were more likely to develop fibrosarcoma tumor models than wild-type mice because of a lack of $\mathrm{CD}^{+} \mathrm{T}$ cell responses. Torti et al. [34] reported a severe deletion of MCMV-specific $\mathrm{CD}^{+} \mathrm{T}$ cells in $\mathrm{Batf3}^{-/-}$mice. Mashayekhi et al. [35] found that $\mathrm{Batf}^{-/-}$mice were more likely to be infected by Toxoplasma gondii due to the lack of CD8 $\alpha^{+}$DCs and decreased IFN $-\gamma$ and IL-12 production.

To evaluate the role of $\mathrm{CD} 8 \alpha^{+}$DCs $\mathrm{s}$ in schistosome infection, we infected $\mathrm{Batf}^{-/-}$and wild-type B6 mice by S. japonicum cercariae. Our results showed that Batf $3^{-/-}$ mice had significantly smaller average size of granuloma in the liver, not because of the difference in schistosome egg or worm burden, suggesting that $\mathrm{CD} 8 \alpha^{+} \mathrm{DCs}$ may be involved in the regulation of the granulomatous response during S. japonicum infection. Furthermore, we found that Tc1 cell responses were stronger in S. japonicum infected $\mathrm{Batf3}^{-1-}$ mice. Opposed to previous studies, our findings suggest that during the infection of $S$. japonicum, the deletion of Batf3 activates $\mathrm{CD} 8^{+} \mathrm{T}$ cells to secrete IFN- $\gamma$ and attenuate liver pathological damage in mice through immune regulation.

$\mathrm{Batf}^{-1-}$ mice can compensatorily produce a certain amount of $\mathrm{CD} 8 \alpha^{+}$DCs through Irf8 transcription factor pathway, the newly generated $\mathrm{CD} 8 \alpha^{+}$DCs express Clec9A on the surface as wild type $\mathrm{CD} 8 \alpha^{+} \mathrm{DCs}$, and have the same cross-presenting function [36]. Thus, $\mathrm{CD} 8 \alpha^{+}$DCs can be divided into Batf3-dependent (Id2Nfil3-Batf3) and Irf8-dependent (PU.1-Irf8) groups. Ashok et al. [37] reported that Batf3 ${ }^{-1-}$ mice infected with Leishmania major lack $\mathrm{CD} \alpha^{+}$DCs cross- 

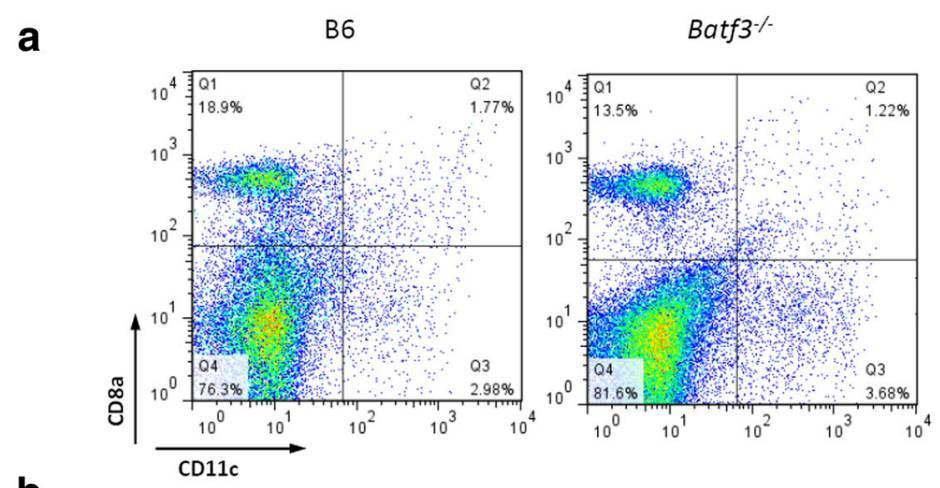
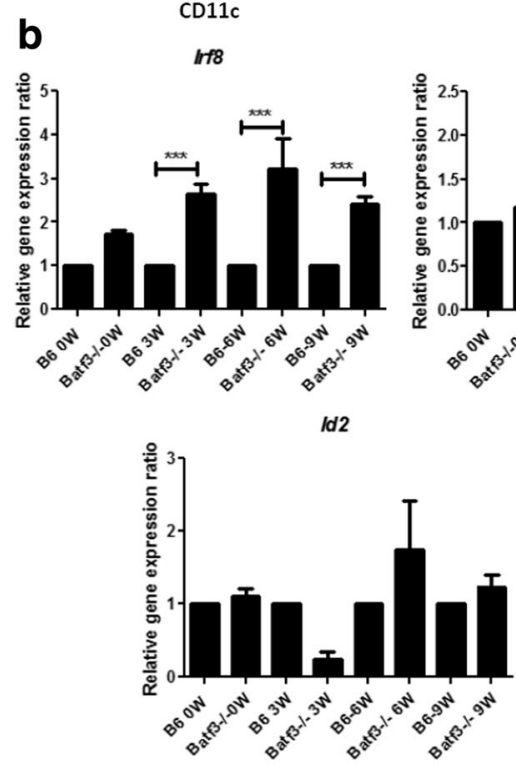

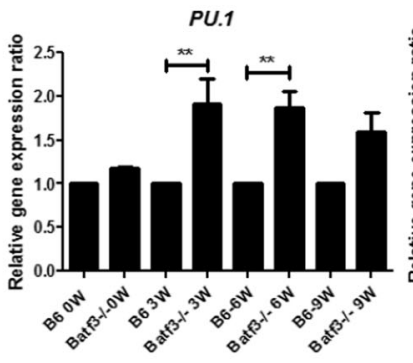

Nfil3

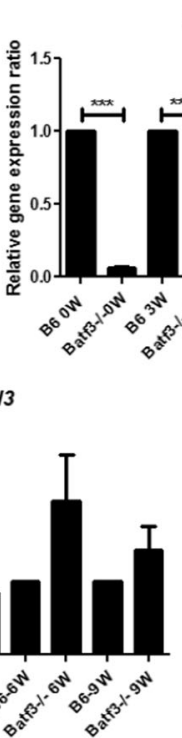

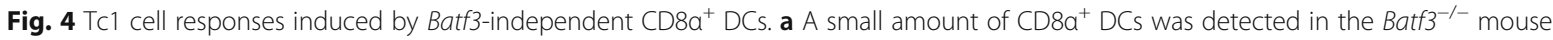
schistosomiasis infection model.Percentages of $\mathrm{CD} 11 \mathrm{c}^{+} \mathrm{CD} 8 \mathrm{a}^{+}$cells analysed by FCM at 9 weeks post-infection. The upper right quadrant is the proportion of $\mathrm{CD}_{8 \mathrm{a}^{+}} \mathrm{DC}$ c cell subsets. b Expression of Irf8, PU.1, Id2, Nfil3 and Batf3genes of Batf3 ${ }^{-1-}$ and B6 mice after S. japonicum infection. Expression of Irf8, PU.1, Id2, Nfil3 and Batf3 genes in the spleen were detected at 0, 3, 6 and 9 weeks post-infection by RT-PCR. (**P<0.01, ***P<0.001) Results are representative of two independent experiments. Data are presented as the mean \pm SEM from six mice in each group

presentation, lymphoid cells secreted less IFN- $\gamma$ and more Th2 and Th17 cytokines, and had severe pathological damage and high worm burden. Sanchez-Paulete et al. [38] reported that because of the lack of crosspresentation activation of tumor antigens and new antigens associated CTLs to participate in immune response, immune regulation monoclonal antibodies lost their enhanced immunotherapeutic effects on tumor therapy in $\mathrm{Batf}^{-/-}$mice. These studies suggest that crosspresentation of Batf3-dependent $\mathrm{CD} 8 \alpha^{+}$DCs in these models is critical. In 2015, Mott et al. [39] found that a small amount of CD8 $\alpha{ }^{+}$DCs could be detected in $\mathrm{Batf3}^{-/-}$mice infected with HSV-1, and HSV-1 latency situation in $\mathrm{Batf3}^{-/-}$mice was not different from wild-type mice, while latent infection was attenuated in BXH 2 mice (Irf8 mutant). This study suggested that cross-presentation of Irf8-dependent $\mathrm{CD} 8 \alpha^{+}$DCs may play a critical role in HSV-1 infection. Cross-presentation of Irf8-dependent $\mathrm{CD} 8 \alpha^{+} \mathrm{DCs}$ may have a key role in schistosomiasis infection.

Irf8 is one member of the interferon regulatory factors family. Irf8 binds to PU.1 protein and forms a complex to regulate the maturation and function of DCs $[40,41]$. In this study we detected a small amount of $\mathrm{CD} 8 \alpha^{+}$DCs in Batf $^{-/-}$mice infected with S. japonicum. Compared with wild-type B6 mice, Irf8 and PU.1 were highly expressed in the spleen cells of $\mathrm{Batf}^{-1-}$ mice. Collectively, our study demonstrated that in the absence of Batf3, a small amount of Batf3-independent CD $8 \alpha^{+}$DCs might be compensatorily induced in an Irf8-dependent manner. These newly generated $\mathrm{CD} 8 \alpha^{+}$DCs may have a more powerful function in cross-presenting and activate $\mathrm{CD} 8^{+} \mathrm{T}$ to secret IFN- $\gamma^{+}$which can attenuate hepatic pathological damage in $\mathrm{Batf3}^{-1-}$ mice. 


\section{Conclusions}

In summary, by using Batf3 $3^{-/-}$mouse model of schistosomiasis japonica, we demonstrate the association of Batf3 with the immunoregulation of the liver granuloma formation without affecting S. japonicum adult worm load and egg production, suggesting an important role for Batf3 in regulation of Tc1 responses in schistosomiasis. We also demonstrated that without Batf3, mice will compensatorily generate Batf3-independent CD $8 \alpha^{+} \mathrm{DC}$. The function of this newly generated $\mathrm{CD} 8 \alpha^{+} \mathrm{DC}$ needs to be further investigated. In addition, these novel findings imply that Batf3 may function as a new therapeutic target if it is directly involved in modulating Tc1 cell responses for schistosomiasis and or other immuneassociated diseases.

\section{Abbreviations}

AOD: IOD/Area; APC: Antigen-presenting cell; Batf3: Basic leucine zipper transcriptional factor ATF-like 3; CD4: Cluster of differentiation 4; CD8: Cluster of differentiation 8; CD8 ${ }^{+} \mathrm{T}(\mathrm{CTL})$ : Cytotoxic T lymphocyte; FCM: Flow cytometry; IFN-ץ: Interferon gamma; IL-4: Interleukin 4; IOD: Integrated optical density; SEA: Soluble egg antigen; Th1: Type $1 \mathrm{~T}$ helper lymphocytes; Th2: Type $2 \mathrm{~T}$ helper lymphocytes

\section{Acknowledgements}

Not applicable.

\section{Funding}

This work was supported by National Natural Science Foundation of China (NSFC) (Project No. 81201300) to Lin Chen. The funders had no role in study design, data collection and analysis, preparation of the manuscript or decision to publish.

\section{Availability of data and materials}

The datasets supporting the conclusions of this article are included within the article.

\section{Authors' contributions}

LC designed and carried out the experiments, analyzed the data and drafted the manuscript. DZ analyzed the data and helped finalize the manuscript. WZ participated in testing the immune responses, $M H, J X, B Y$ and $Y Z$ participated in the animal experiments. MJ and GW contributed the reagents and materials and helped draft the manuscript. All authors read and approved the final manuscript.

\section{Competing interests}

The authors declare that they have no competing interests.

\section{Consent for publication}

Not applicable.

\section{Ethics approval}

Experiments involving animals were performed in strict accordance with the Regulations for the Administration of Affairs Concerning Experimental Animals (1988.11.1), and all animal procedures were approved by the Institutional Animal Care and Use Committee (IACUC) of Nanjing Medical University for the use of laboratory animals. All the mice were subjected to minimum suffering.

\section{Publisher's Note}

Springer Nature remains neutral with regard to jurisdictional claims in published maps and institutional affiliations.

\section{Author details}

${ }^{1}$ Department of Pathogen Biology, Nanjing Medical University, Nanjing, Jiangsu, China. ${ }^{2}$ Jiangsu Province Key Laboratory of Modern Pathogen
Biology, Nanjing, Jiangsu, China. ${ }^{3}$ School of International Education, Nanjing Medical University, Nanjing, Jiangsu, China. ${ }^{4}$ Institute of Dermatology, Chinese Academy of Medical Sciences and Peking Union Medical College, Nanjing, China.

Received: 12 April 2017 Accepted: 15 June 2017

Published online: 24 June 2017

\section{References}

1. Wang Tian-ping CZ-G, Dan-dan L, Xiao-nong Z. Scientific research priority and prospect of schistosomiasis during the 12th five-year lan period in China. Chin J Schisto Control. 2011;23:111-3.

2. Lewis FA, Tucker MS. Schistosomiasis. Adv Exp Med Biol. 2014;766:47-75.

3. Fallon PG, Mangan NE. Suppression of TH2-type allergic reactions by helminth infection. Nat Rev Immunol. 2007;7:220-30.

4. Dunne DW, Cooke A. A worm's eye view of the immune system: consequences for evolution of human autoimmune disease. Nat Rev Immunol. 2005:5:420-6.

5. Butterworth AE, Vadas MA, Martz E, Sher A. Cytolytic T lymphocytes recognize alloantigens on schistosomula of Schistosoma mansoni, but fail to induce damage. J Immunol. 1979;122:1314-21.

6. Chensue SW, Wellhausen SR, Boros DL. Modulation of granulomatous hypersensitivity. II. Participation of Ly $1+$ and Ly $2+T$ lymphocytes in the suppression of granuloma formation and lymphokine production in Schistosoma mansoni-infected mice. J Immunol. 1981;127:363-7.

7. Ragheb S, Boros DL. Characterization of granuloma T lymphocyte function from Schistosoma mansoni-infected mice. J Immunol. 1989;142:3239-46.

8. Fidel PL Jr, Boros DL. Regulation of granulomatous inflammation in murine schistosomiasis. IV. Antigen-induced suppressor T cells down-regulate proliferation and IL-2 production. J Immunol. 1990;145:1257-64.

9. Pancre V, Wolowczuk I, Guerret S, Copin MC, Delanoye A, Capron A, et al. Protective effect of rSm28GST-specific T cells in schistosomiasis: role of gamma interferon. Infect Immun. 1994;62:3723-30.

10. Pancre V, Gras-Masse H, Delanoye A, Herno J, Capron A, Auriault C. Induction of cytotoxic T-cell activity by the protective antigen of Schistosoma mansoni Sm28GST or its derived C-terminal lipopeptide. Scand J Immunol. 1996:44:485-92.

11. Zhang M, Gao Y, Du X, Zhang D, Ji M, Wu GL. Toll-like receptor (TLR) 2 and TLR4 deficiencies exert differential in vivo effects against Schistosoma japonicum. Parasite Immunol. 2011;33:199-209.

12. Tian F, Lin D, Wu J, Gao Y, Zhang D, Ji M, et al. Immune events associated with high level protection against Schistosoma japonicum infection in pigs immunized with UV-attenuated cercariae. PLoS One. 2010;5:e13408.

13. Pedras-Vasconcelos JA, Pearce EJ. Type 1 CD8 ${ }^{+} T$ cell responses during infection with the helminth Schistosoma mansoni. J Immunol. 1996;157: 3046-53.

14. Czaja MJ, Weiner FR, Takahashi S, Giambrone MA, van der Meide PH, Schellekens $\mathrm{H}$, et al. Gamma-interferon treatment inhibits collagen deposition in murine schistosomiasis. Hepatology. 1989;10:795-800.

15. Fallon PG, Smith P, Dunne DW. Type 1 and type 2 cytokine-producing mouse CD4 ${ }^{+}$and CD8+ T cells in acute Schistosoma mansoni infection. Eur J Immunol. 1998;28:1408-16.

16. Hildner K, Edelson BT, Purtha WE, Diamond M, Matsushita H, Kohyama M, et al. Batf3 deficiency reveals a critical role for CD8alpha+ dendritic cells in cytotoxic T cell immunity. Science. 2008;322:1097-100.

17. Livak KJ, Schmittgen TD. Analysis of relative gene expression data using real-time quantitative PCR and the 2(-Delta Delta C(T)) method. Methods. 2001;25:402-8.

18. Ross AG, Bartley PB, Sleigh AC, Olds GR, Li Y, Williams GM, et al. Schistosomiasis. N Engl J Med. 2002;346:1212-20.

19. Gryseels B, Polman K, Clerinx J, Kestens L. Human schistosomiasis. Lancet. 2006:368:1106-18.

20. Ashton PD, Harrop R, Shah B, Wilson RA. The schistosome egg: development and secretions. Parasitology. 2001;122:329-38.

21. Hirata M, Kage M, Hara T, Yoneda Y, Zhang M, Fukuma T. Schistosoma japonicum egg granuloma formation in the interleukin-4 or interferongamma deficient host. Parasite Immunol. 2001;23:271-80.

22. Rutitzky LI, Stadecker MJ. Exacerbated egg-induced immunopathology in murine Schistosoma mansoni infection is primarily mediated by $\mathrm{LL}-17$ and restrained by IFN-gamma. Eur J Immunol. 2011;41:2677-87. 
23. Kaplan MH, Whitfield JR, Boros DL, Grusby MJ. Th2 cells are required for the Schistosoma mansoni egg-induced granulomatous response. J Immunol. 1998;160:1850-6.

24. Edelson BT, Kc W, Juang R, Kohyama M, Benoit LA, Klekotka PA, et al. Peripheral $\mathrm{CD}_{103^{+}}$dendritic cells form a unified subset developmentally related to CD8alpha ${ }^{+}$conventional dendritic cells. J Exp Med. 2010;207: 823-36.

25. Bevan MJ. Cross-priming. Nat Immunol. 2006;7:363-5

26. Shortman K, Liu YJ. Mouse and human dendritic cell subtypes. Nat Rev Immunol. 2002;2:151-61.

27. Ardavin C. Origin, precursors and differentiation of mouse dendritic cells Nat Rev Immunol. 2003;3:582-90.

28. Pooley JL, Heath WR, Shortman K. Cutting edge: intravenous soluble antigen is presented to CD4 T cells by CD8 ${ }^{-}$dendritic cells, but crosspresented to $C D 8^{+} T$ cells by $C D 8^{+}$dendritic cells. J Immunol. 2001;166: 5327-30.

29. Schnorrer P, Behrens GM, Wilson NS, Pooley JL, Smith CM, Sukkari D, et al. The dominant role of $\mathrm{CD}^{+}$dendritic cells in cross-presentation is not dictated by antigen capture. Proc Natl Acad Sci USA. 2006;103:10729-34.

30. Belz GT, Nutt SL. Transcriptional programming of the dendritic cell network. Nat Rev Immunol. 2012;12:101-13.

31. Kashiwada M, Pham NL, Pewe LL, Harty JT, Rothman PB. NFIL3/E4BP4 is a key transcription factor for CD8alpha(+) dendritic cell development. Blood. 2011;117:6193-7.

32. Miller JC, Brown BD, Shay T, Gautier EL, Jojic V, Cohain A, et al. Deciphering the transcriptional network of the dendritic cell lineage. Nat Immunol. 2012; 13:888-99.

33. Desch AN, Randolph GJ, Murphy K, Gautier EL, Kedl RM, Lahoud MH, et al. CD103+ pulmonary dendritic cells preferentially acquire and present apoptotic cell-associated antigen. J Exp Med. 2011;208:1789-97.

34. Torti N, Walton SM, Murphy KM, Oxenius A. Batf3 transcription factordependent $D C$ subsets in murine CMV infection: differential impact on Tcell priming and memory inflation. Eur J Immunol. 2011;41:2612-8.

35. Mashayekhi M, Sandau MM, Dunay IR, Frickel EM, Khan A, Goldszmid RS, et al. CD8alpha(+) dendritic cells are the critical source of interleukin-12 that controls acute infection by Toxoplasma gondii tachyzoites. Immunity. 2011; 35:249-59.

36. Seillet C, Jackson JT, Markey KA, Brady HJ, Hill GR, Macdonald KP, et al. CD8alpha+ DCs can be induced in the absence of transcription factors Id2, Nfil3, and Batf3. Blood. 2013;121:1574-83.

37. Ashok D, Schuster S, Ronet C, Rosa M, Mack V, Lavanchy C, et al. Crosspresenting dendritic cells are required for control of Leishmania major infection. Eur J Immunol. 2014;44:1422-32.

38. Sanchez-Paulete AR, Cueto FJ, Martinez-Lopez M, Labiano S, MoralesKastresana A, et al. Cancer immunotherapy with immunomodulatory antiCD137 and anti-PD-1 monoclonal antibodies requires BATF3-dependent dendritic cells. Cancer Discov. 2016;6:71-9.

39. Mott KR, Maazi H, Allen SJ, Zandian M, Matundan H, Ghiasi YN, et al. Batf3 deficiency is not critical for the generation of CD8alpha(+) dendritic cells. Immunobiology. 2015;220:518-24

40. Tamura T, Yanai H, Savitsky D, Taniguchi T. The IRF family transcription factors in immunity and oncogenesis. Annu Rev Immunol. 2008;26:535-84.

41. Carotta S, Willis SN, Hasbold J, Inouye M, Pang SH, Emslie D, et al. The transcription factors IRF8 and PU.1 negatively regulate plasma cell differentiation. J Exp Med. 2014;211:2169-81.

\section{Submit your next manuscript to BioMed Central and we will help you at every step:}

- We accept pre-submission inquiries

- Our selector tool helps you to find the most relevant journal

- We provide round the clock customer support

- Convenient online submission

- Thorough peer review

- Inclusion in PubMed and all major indexing services

- Maximum visibility for your research

Submit your manuscript at www.biomedcentral.com/submit

Biomed Central 